\title{
Professionalizing Teaching Identity and Teaching 'Excellence' Schemes
}

\author{
Ming Cheng
}

Introduction

Understanding 'academic identity' is important in helping to explain academics' belief systems and actions (Fanghanel 2012). Some writers see academic identity as related to different academic roles and disciplinary areas (Becher and Trowler 2001). For others, it is something undergoing a massive transformation, as new divisions of labour in higher education (HE) lead to re-defined notions of academic professionalism (Fanghanel 2012; Barry et al. 2006; Nixon 2003; Nixon et al. 2001). Specific factors may also influence perceptions of identity. These include the type of university involved, academics' professional role and status, employment type, level of seniority and career specialization (Clegg 2008; Blackmore and Blackwell 2006; Sikes 2006; Enders 2005; Henkel 2005).

\section{Teaching identity}

In order to take forward some of these considerations, this chapter explores academics' identity in and through their teaching. Teaching constitutes a fundamental part of academic work (Clegg 2008: 330), where notions of individual autonomy and control are most valued: a deep sense of engagement with teaching, Clegg argues, creates space for the exercise of personal autonomy. There is also an increasing emphasis on university teaching in the UK, which is lately indicated by the Browne Report (2010) and awards of national teaching fellowships by the Higher Education Academy (HEA). These developments suggest a trend for notions of 'good practice' in HE teaching to be encouraged and rewarded (Turner and Gosling 2012), more 'embedded' in mainstream academic employment and institutional policy perhaps, than hitherto.

This chapter seeks to provide an insight into how individual academics understand their identity as academics when there is an increased importance given to teaching at the national level. It will explore whether winning a university teaching award 
reinforces and disseminates 'good practice' within an institution, and the reasons for this. Understanding perceptions is important, because there is limited research into whether the growth of teaching award schemes is really linked to academics' own values about the importance of teaching (Kreber 2000; Macdonald 1998). For example, Fanghanel and Trowler (2008) have argued that award schemes misrepresent the nature of academic work. Critically, they suggest that these have not created cohesion between teaching and research activities at all. Similarly, Turner and Gosling (2012: 415) observe that many staff have expressed detachment from teaching recognition schemes in HE.

\section{Professionalizing teaching identity}

Of the different interpretations of academic identity, one view is that academics are loyal primarily to their subject areas (Becher and Trowler 2001; Healey 2000). This view is closely linked to an image of academics as the 'products' of traditional disciplines, in a quest for scholarly knowledge, and detached from the world of everyday life (Beck 2002). For some writers, academics formerly gained autonomy and status from their membership of such a professional community - their subject grouping - which protected them from the external influences of the government (Beck and Young 2005; Kogan and Hanney 2000). However, the marketization, expansion and diversification of HE (David 2011), together with quality and audit processes, and the development of new ways of teaching and assessment, have arguably led to the emergence of some new forms of academic 'professionalism', discussed also in Section IV of this volume. These are particularly in relation to 'pedagogy' or consideration of the nature and practice of teaching (Nixon 2003, 1996). Nixon describes them as involving a new form of agreement-making between professionals and their publics, where academics sense their identity as something derived from a capacity to learn from, listen to and move forward with the communities they serve.

Related to this, institutional and policy mechanisms, including the setting up and funding of Teaching and Learning 'practice' centres in the UK (CeTLs), have thus become established in order to encourage, stimulate and resource such practitioner learning and development (Sikes 2006; Skelton 2005). The Higher Education Funding Council for England (HEFCE) has assumed the management of the Teaching Quality Enhancement Fund (TQEF) (1999-2009), the 'Centres of Excellence in Teaching and Learning' (CETL) network, and the Higher Education Academy (HEA) in order to underpin and develop institutions' own and the sector's Learning and Teaching strategies (HEA 2008a). The HEA itself provides a national focus for institutional teaching and learning excellence through the National Teaching Fellowship Scheme (NTFS), to reward academics in teaching in England and Northern Ireland (HEA 2008b). As a result, all HE institutions today are encouraged to recognize and reward 'outstanding individual teaching achievement' corresponding with these national schemes.

There has been a gap in qualitative research however, and evaluation of Teaching Awards recognition, while those studies available have been mainly confined to the national schemes (Gibbs 2000). There is a view, that in order to encourage involvement 
in 'teaching excellence', by both academics and their subject groupings within the discipline areas (Trowler et al. 2005; Skelton 2004; Warren and Plumb 1999), and to build wider credibility, that 'evaluation' needs to be set within institutional contexts. There is thus an opportunity to contribute data from case studies of individual institutions.

\section{Research methods}

This chapter will explore how the 'winners' of Teaching Excellence Awards in a 'post-1992' modern UK university viewed the impact of winning the award on their own teaching identity as HE professionals. The aim is to explore understandings of how academics' teaching is valued personally and extrinsically, and to consider how this relates to notions of 'good teaching practice' in HE. The winners (my informants) were nominated for outstanding contributions to student learning by their colleagues and students. From this, two research questions were developed, to consider:

1 the effect of winning a Teaching Excellence Award on the winners' own selfperception as 'teachers in HE'.

2 The extent of the impact of winning the award on the encouragement of good pedagogic practice more widely within the institution.

Seventeen interviews were conducted, comprising university Teaching Excellence Award winners $(n=15)$, together with two panel members $(n=2)$ of the award scheme's board. The semi-structured, interpersonal nature of each interview enabled attention to be paid to individual differences. The interviewees were from six different schools/departments, and were selected to provide a representative group of academics based on gender, subject area, experience and seniority. The informants included professors, principal lecturers and senior lecturers. Three had also received National Teaching Fellowship Awards. Each interview began with a short briefing about the project, and care was taken not to 'cue' participants to formulate responses in line (or otherwise) with the study. It was also important to ensure that the identity of interviewees was sufficiently anonymized and could not be deduced through the use of 'quoted' material.

\section{Findings: perceived identity as teachers}

There was considerable common ground in how the award winner interviewees considered their teaching identity. Unanimously, they related this to the disciplines they worked in. This corresponds with the argument that 'disciplinary differences' influence how academics understand their core professional identity (Becher and Trowler 2001; Healey 2000; Becher 1994). For example, a male lecturer in occupational health described his identity as both a teacher and as an occupational therapist: 'It's true that you normally say your profession first. I might say that I was an occupational therapist, but I would see myself as, um, as now of course after so many years, first as a teacher' (TEA3). 
'Teacher' and 'lecturer' were the most frequently used words to describe interviewees' identity as teachers. Eleven of the interviewees called themselves lecturers or teachers, and six preferred the title of 'teachers' to that of 'lecturers', which is interesting in an HE setting. One reason was that they thought people outside the academy might perceive a university lecturer as a 'pompous person' who 'knows it all', and as someone who was unapproachable. The other reason given was that the term 'teacher' was also easier to understand for outsiders. A female interviewee from the School of Business further explained her feeling that the term 'lecturer' was connected not only with teaching, but also with individual personality factors together with the development of teaching skills in a specific discipline:

I think if you are a really good teacher [then] you can teach, not almost anything [but] some things. My communication skills and my ability to explain something fundamentally well ... [is over and above what] I do within the sphere of the legal environment.

TEA1

One male participant in the study expressed doubts about whether 'teacher' or 'lecturer' would be the best terms to describe his teaching identity. He referred to this as principally being 'in the classroom with the students'; in other words, as something relational and interactive:

I love what I do but the main thing is the teaching, and I know 'teacher' doesn't really describe what I do in terms of [labelling me as] the 'wise one' and you need to learn from me. I do see it as a group activity. 'Lecturer' just sounds - but I don't give lectures - so I'm not quite sure what the word is. But that's the biggest buzz, the actual being in the classroom with the students.

TEA11

The above comments illustrate what most interviewees said, that they related their teaching identity attributes to values and activities around helping students. Teaching skills, subject specialism and the 'understanding of teaching' were thought of as the key elements that informed this sense of occupational identity and also personal self-worth. This can be understood as aspects of the 'knowledge base' for teaching, as well as dimensions of pedagogical professional knowledge in HE (Berthiaume 2007). They also connect to notions of the 'emotional' content and context of teaching/academic work referred to in Part I of this volume, and by Huyton in her work on personal tutoring in HE.

\section{Valuing teaching}

There have been a number of studies on the understandings of teaching (Pratt et al. 1998) and of how academics experience their work in this area (Malcolm and Zukas 2009; Prosser and Trigwell 1999; Trigwell 1995, 2000; Trigwell and Prosser 1997). From them, we see that individual conceptions of teaching often illustrate one of two 
views: teachers who see their primary role as conveying special or general knowledge, and those who see their 'teacherly' role as to develop students' own conceptions of learning. The former is a fairly 'traditional' perspective, and while it has its place, would not today be regarded by many lecturers or others as very progressive in pedagogical terms. Unsurprisingly then, and in this 'new university' context, most of the interviewees in this study identified with the latter view. But beyond this, they also saw their teaching as a process of stimulating the desire of students to learn, and to become independent learners themselves. This approach, of teaching for 'learner autonomy', is also discussed in Part IV of this book (Ecclesfield and Garnett; Rogers).

All the award winners I interviewed saw university teaching as a 'rewarding job': their teaching would enable students to see that there were opportunities beyond the life they currently had, as well as giving different ways of thinking, that went beyond normal or 'typical' modes. Again, teaching would give students confidence in learning, and thus develop independent skills, enabling them to 'keep on learning', something Nixon (2011) discusses in the context of the 'public' role of HE. As a result, they could flourish creatively, developing their own 'enquiring' and cognitive ability through out life. A third view was that teaching could help relate students' learning to work practices, and help them to feel 'empowered' in the labour market. These perceptions suggest that the award winners understood their pedagogic role as a complex one, where they not only presented ideas and concepts through teaching and professional engagement, but also led students to think how to act on these now and in the future. The conceptualizations suggested that 'teaching' was considered as something far more than an 'occupational activity', but as a 'professional calling' and 'vocation', with moral responsibility for the students' beneficial learning experience and ongoing development (Carr 2006).

The informants in my study affirmed that they were proactive in motivating and inspiring student learning. Positive changes in students then reciprocally affirmed and stimulated teachers' own valuing of and passion for teaching, increasing their own confidence and enthusiasm. A male interviewee from the School of Law was impressed by students' motivation in attending his course, even though they did not receive any credits: 'One of the things that struck me the most about the law student participation [is that] whereas the police students have to do it and they are being assessed, the law students volunteer' (TEAW7). Another interviewee from a Health Professions school described students' increased confidence after undertaking her course:

Students say they're coming back with a greater confidence in themselves and in their knowledge [base]. They're coming back with a sense that they've done some good, which has made them feel that they've actually made a difference to people's lives.

TEAW6

This 'virtuous circle' helped to create active and independent learning among students, and consequently was perceived by academics in the study to have made them feel as 'equal participants' in the learning process. A female interviewee from a business studies background emphasized how treating her students as 'equals' could bring the benefit of different information and experience to the class: 
In my practice, I don't ever see myself as passing on 'knowledge'. It's about stimulating knowledge [development] ... because they've all been exposed to media of some kind, film, TV, [whereas] obviously I can't see everything that's available to see.

TEAW 12

The 'teaching excellence' interviewees affirmed the role identified in the literature (Biggs and Tang 2011) of 'committed teaching' as contributing to student learning. They related students' intellectual achievements to the notion of teaching as a 'rewarding profession'. However, it has to be stated that few distinguished academic careers appear to have emerged to date solely through the 'teaching' route - as a number of observers have commented (Sikes 2006; Young 2006) - or at least ones that have been widely celebrated and valorized in the sector.

\section{Perceived value of the award}

Apart from two academic interviewees who commented that winning the award had little impact on their identity and practice, the remaining 13 acknowledged its value. They found that it had strengthened and professionalized their sense of 'academic identity' as teachers, and further increased their commitment to teaching itself. This does support the view (promoted by agencies like the HEA) that teaching awards could work as a strong incentive to improve academic practice. Indeed, they are becoming a standard way for institutions to give recognition for this role (Carusetta 2001; Seldin 1999; Wright 1995). When good teaching is rewarded and sustains academics' commitment to the improvement of the pedagogical role, it creates positive feedback cycles - and a strong practical argument for institutions to explicitly honour the scholarly work of teaching. The two interviewees who attached 'limited importance' to winning the award included one who was from a modern languages background, who did not want to be perceived by students as a 'special' teacher simply because of the award. This is also identified and discussed by Turner and Gosling (2012). This lecturer's goal was to help students think in a way that they would not do otherwise: 'I want students to feel that I'm an excellent teacher or an interesting teacher because I showed them something which otherwise life might not have shown them ... [and not because of winning an award]' (TEA10).

The study also revealed that though the participants spanned the age and career ranges of academic professionals, the value of the award was better appreciated by early-career academics than by their more established colleagues. A professor explained:

My profile had already been established before I got the teaching award. If I was a new, a relatively new lecturer ... I'm sure that it would probably have motivated me to do things that perhaps I wouldn't have thought of doing before.

TEA4

This participant accepted that an award was more likely to motivate a relatively new lecturer to innovate, take risks and experiment. Another interviewee saw the role of 
the award as an explicit institutional affirmation that teaching and learning were important:

It shows [that] the university values teaching and the learning of students of course, that's the most important. It shows that [the university] values learning - student learning - more than just valuing research

(TEA3).

Thirteen of the interviewees appreciated the value of the award as beneficial to teaching at both institutional and individual level. However, they were also aware that, although the award would encourage wider interest in 'good teaching' in the institution, it had not necessarily increased the status of teaching per se within the university. Research was still being prioritized in 'status' terms (Ginns et al. 2010). There was a feeling that the institution wanted to use the award scheme to improve its profile for teaching quality (as attractive for students). This was seen to be (driven) by external competitiveness factors rather than professional/pedagogical values, as the university in fact became more research-intensive. It is paradoxical: the award scheme, despite its 'success', had not effectively improved feelings about the status of teaching in the institution, or redressed the perceived 'imbalance' between teaching and research there (NCIHE 1997: para. 8.9; see also Walker 2006). Nevertheless, the teaching award at the case study institution was perceived by two-thirds of the interviewees as a morale-boosting way to acknowledge those academics who had developed good teaching and learning practice with students and courses. Terms used included: [it is] 'an accolade,' 'a nice gesture,' 'a launch platform' from which to try new ways of teaching:

The award is [a] kind of 'backing' to me to sort of say 'Well, you're an award winner', there's almost an expectation that you're going to push the envelope and try new things, because what you've done up to now works, has been recognized, i.e. 'don't stop there, keep going. So it's, yeah, it's a kind of launch platform.

TEA2

Another interviewee from the Media School also described the 'accolade' as a motivation to further develop and improve, putting more ideas into practice:

To be recognized for what you do is obviously very flattering ... and gives you the motivation and the sense to carry on ... taking your best practice forward for what you've been recognized for doing

(TEA12).

Thirteen of the study participants had a sense that, although their teaching practice as a whole would not necessarily shift dramatically as a result of winning the award, it was a tangible, personal and public recognition of teaching competence and professional success in a key area. They planned to include it on their CVs. A lecturer from the School of Law commented on the 'boost' to his own confidence: 
I have always seen myself ... as a competent teacher as well as a lecturer, as a facilitator of learning, and that award sort of consolidates that feeling that I had about that aspect of my role

(TEAW7).

This increased confidence expressed by many of the interviewees suggests that winning the award worked as more than 'tokenism' for the academics involved. While many recent $\mathrm{HE}$ changes might have reduced the confidence and self-esteem of some academic staff, the award reinforced their sense of agency as pedagogically-engaged professionals. Interviewees valued this sense of greater self-esteem brought to them by the 'external' recognition and wanted to improve further. It showed that the institution agreed with them in valuing and perhaps prioritizing teaching, and the importance of developing more 'teaching knowledge' strategies. Perhaps the greatest reward, however, was that the recognition arose from the assessments of their students and colleagues.

\section{Concluding remarks}

This chapter has explored how winners of an excellence award in a post-1992 university in the UK interpreted the impact of this on their understanding of themselves as academics and teachers. It revealed that most felt that 'research' in the institution was still prioritized, yet that winning the award did reinforce their own sense of professional engagement, and that the scheme had given public recognition to what they most valued in their work - teaching. On a broader note, the scheme had not significantly increased the status of teaching or work with students within the institution, they thought, even though it was within the 'modern' university sector.

Not all academics are convinced of the value of teaching awards schemes (Turner and Gosling 2012; see also Waring this volume). However, there is now a growing community of teaching-rewarded academics in $\mathrm{HE}$, and their comments on the importance of teaching, student interaction, engagement and learning, are arguably values that are common across the academic profession and institutional types (Fanghanel 2012). Perhaps it is the case that these now constitute a growing and increasingly important 'advocacy' group for academics' teaching role in HE. 